\title{
Urine Immunofixation Electrophoresis
}

National Cancer Institute

\section{Source}

National Cancer Institute. Urine Immunofixation Electrophoresis. NCI Thesaurus. Code C135569.

An immunofixation-based laboratory test performed to detect and type monoclonal immunog lobulins present in a urine sample. 